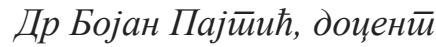

Правної факулиетей у Новом Саду

\title{
ЕКОЛОШКА ОДГОВОРНОСТ ${ }^{1}$
}

Сажейак: Имајући у виду нарасӣајући значај йроблемайике оді̄о-

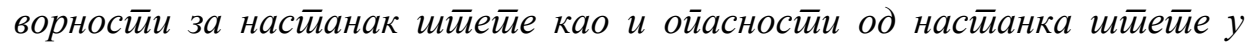
кониекстиу зашимитие живойне средине на нивоу Евройске уније, у овом раду је йосебно обрађена ирроблемайика йзв. еколошке одіоворносиии и њеноі реїулисања на нивоу ЕУ, као и имйлеменайиије ове устианове у йоједина начионална законодавстива. Анализа је извршена йолазећи од сайледа-

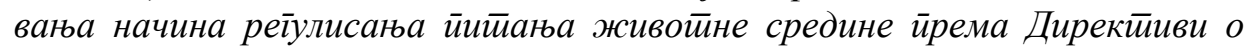
еколошкој одіоворносиии, а йосебан акиенай је стиављен на имйлеменйаиију ове Дирекиииве у йојединим државама чланицама ЕУ.

Кључне речи: еколошка одіоворности, еколошка шиеейа, ірађанско ирраво, накнада шимеиее, заїађивач йлаћа

\section{1. Уводна разматрања}

Заштита животне средине на ниву Европске Уније се не може стриктно одвојити на грађанскоправну и јавноправну заштиту и из тог разлога се дефинише као интегрална заштита која нужно подразумева и координацију и сарадњу различитих органа власти и то првенствено правосудних и управних органа власти. У тој интегралној заштити поједине гране права имају специфичне улоге. Тако и грађанско право има посебно значајну улогу у заштити животне средине којом се обезбеђује адекватна превенција и реституција у овој области. Иако се примарно грађанскоправна заштита односи на

${ }^{1}$ Рад је настао као резултата истраживања у првој години рада на Пројекту „Теоријски и практични проблеми у стварању и примени права (ЕУ и Србија)“ чији носилац је Правни факултет Универзитета у Новом Саду. 
природне вредности, у савременом свету постоји приметна тенеденција да се она прошири и на људским радом створене вредности што је последица правног дефинисања животне средине као скупа природних и људским радом створених вредности. Заштита животне средине која се остварује по правилима облигационог права је превентивна и последично-реститутивна. У грађанскоправном смислу штета представља умањење туђе имовине или спречавање њеног увећања - материјална штета, као и наношење физичког и душевног бола, односно изазивање страха одређеног интензитета и трајања - нематеријална штета. Ипак, штетне последице које настају у животној средини немају за последицу грађанскоправну одговорност јер се не могу увек подвести под појам штете у грађанскоправном смислу. Грађанскоправна одговорност постоји уколико је штета на заштићеним добрима мерљива и уколико се последица састоји у угрожавању или повреди личних имовинских или неимовинских добара неког физичког или правног лица. Ове штете се отклањају средствима класичног одштетног права. У нашем законодавству је спречавање штете на заштићеним добрима један од основних циљева правне политике заштите животне средине, што је у складу и са међународним документима из ове области којима се превентивно деловање подиже на ниво основног начела. У том контексту је значајно поменути и два основна начела права животне средине, а то су начело „корисник плаћа“ и начело „загађивач плаћа“ која су предвиђена и код нас. У складу са правилима одштетног права заштићена добра се доводе у одговарајуће стање о трошку одговорног лица. Одређене превентивне и реститутивне мере се финансирају средствима из општих фондова у које се сливају накнаде које загађивачи плаћају због оптерећења или загађења животне средине. Физичка и правна лица која користе природне вредности дужна су да плате реалну накнаду и да сносе трошкове рекултивације простора. Ова средства су део наменских фондова из којих држава финансира различите мере које доприносе одрживом развоју и заштити животне средине. Законом о заштити животне средине $^{2}$ је прописано да свака активност мора бити планирана и спроведена на начин да проузрокује најмању могућу промену у животној средини, представља најмањи могући ризик по животну средину и здравље људи, смањи оптерећење простора и потрошњу сировина и енергије у изградњи, производњи, дистрибуцији и употреби, обезбеду могућност рециклаже, спречи или ограничи утицај на животну средину на самом извору загађења. Питања која нису обухваћена посебним прописима, решавају се у по општим правилима Закона о облигационим односима о превентивном деловању. ${ }^{3}$ У слу-

\footnotetext{
${ }^{2}$ Службени гласник РС број 135/2004, 36/2009, 36/2009 - др. закон, 72/2009 - др. закон и 43/2011 - одлука УС

${ }^{3}$ Службени лист СФРЈ број 29/78, 39/85, 45/89 - одлука УСЈ и 57/89, Службени лист СРЈ број 31/93 и Службени лист СЦГ број 1/2003 - Уставна повеља
} 
чају штете која настане услед обављања општекорисне делатности у складу са дозволом надлежног органа, може се захтевати само накнада штете која прелази прописане границе, али оштећени и тада може да тражи да одговорно лице предузме мере за спречавање штетних последица или њихово смањење. ${ }^{4}$ У Закону о заштити животне средине је одговорност за штету регулисана одвојено од одговорности за загађење. За загађење животне средине су одговорни загађивачи као и лица која су незаконитим или неправилним деловањем омогућила или допустила да до загађења дође. За насталу штету одговара загађивач по принципу објективне одговорности и тада доказује постојање штете и узрочне везе између његових поступака и наступелих штетних последица, а загађивач сноси трошкове процене штете и штетних последица које су наступиле. Он је такође дужан да надокнади издатке који су настали услед хитних интервенција које су предузете у време настанка штете, а које су биле неопходне за ограничавање и спречавање негативних ефеката по животну средину. Сам загађивач сноси трошкове санације, трошкове спречавања штете (исте или сличне) у будућности и трошкове накнаде оштећеним лицима. У том смислу је сам загађивач Законом обавезан да се осигура од одговорности за штету уколико има постројење или врши делатност од којих потиче висок степен опасности по здравље људи и животну средину. Оштећени може да тражи обештећење непосредно од самог загађивача или осигуравача, тј. финансијског гаранта загађивача. Уколико је штету проузроковао већи број загађивача, њихова одговорност је солидарна. Потраживање застарева у року од три године од сазнања оштећеног за наступелу штету и штетника (субјективни рок), а најкасније у року од двадесет година од настанка штете (објективни рок). Одговорност за секундарне последице загађења је регулисана Законом о заштити животне средине, а на питања која нису регулисана посебним прописима се примењују општа правила Закона о облигационим односима и другим прописима из области грађанског права. Одговорно лице је свако лице (физичко и правно) које је загадило заштићена добра или је створило повећани ризик од наступања таквих последица. Сваки загађивач може да одговара по правилима грађанскиг, кривичног или управног права. Одговорност за загађење је јаваноправне природе, одговорност за секундарне последице загађења је углавном приватноправна, у првом случају штета погађа друштво, а у другом првенствено појединачне интересе. ${ }^{5}$

\footnotetext{
${ }^{4}$ Видети: члан 156. став 3. и 4. 300

${ }^{5}$ Више видети: Ј.Салма и група аутора, Основе права животне средине, Нови Сад 2009., стр.183-184.
} 


\section{2. Директива о еколошкој одговорности ${ }^{6}$}

Априла 2004. године на снагу је ступила Директива Европске уније о еколошкој одговорности којом се уводи систем одговорности за штету у животној средини насталу људском (индустријском) делатношћу. Ова Директива регулише еколошку одговорност и спречавање и отклањање штете настале у животној средини. Директива обезбеђује директну примену принципа „загађивач плаћа“, уводи концепт еколошке штете и низ мера и поступака у циљу спречавања и отклањања настале штете. У вези са овим питањем потребно је напоменути да се данас све више спомиње и појам корпоративне друштвене одговорности која представља посвећеност предузећа да допринесе одрживости привредног развоја сарађујући са запосленима, њиховим породицама, локалном заједницом и друштвом уопште у циљу побољшања њиховог живота.

Питање еколошке одговорности нужно захтева и дефинисање појма еколошке штете. Еколошка штета укључује штету над заштићеним врстама и стаништем, загађење земље и воде. Штета над заштићеним врстама и стаништем настаје у случају значајнијих штетних утицаја на успостављање и одржавање позитивног стања заштићених станишта и врста. Шета над еколошким системом не односи се само на штету над еколошким системом већ заштићеним европским ${ }^{7}$ или националним правом. Грађанскоправна одговорност за штету на нивоу ЕУ је регулисана Конвенцијом Савета Европе о грађанској одговорности за штету проузроковану обављањем делатности опасне по животну средину која је донета 1993. године у Лугану. Заснована на принципу „загађивач плаћа“, ова Конвенција широком дефиницијом одговорности олакшава терет доказивања титуларима права на накнаду штете. Конвенција се односи на сва физичка и правна лица која имају утицаја и врше контролу над обављањем одређене опасне делатности. То значи да се лица са одштетним захтевом за штету претрпљену над имовином, животом или здрављем изазваном еколошком штетом или непосредном опасности од еколошке штете, не могу се позвати на Директиву. Права таквих лица су регулисана националним правом, односно поменутом Конвенцијом уколико је ратификована и имплементирана у национално законодавство. Иако уводи јединствени европски систем спречавања и интегралне накнаде еколошке штете, Директива нема ретроактивно

${ }^{6}$ Директива 2004/35/СЕ Европског парламента и Савета од Априла 2004 о одговорности за еколошку штету у вези са заштитом и отклањањем еколошке штете, OJ L 143, 30.4.2004.

${ }^{7}$ Члан 2 (1) (а) $2 \S$ і (3); Директива 79/409/ЕСС од 02. априла 1979. о очувању дивљих птица и Директива 92/43/EЕС од 21. маја 1992 о очувању природног станишта и дивље флоре и фауне. 
дејство. Она се односи на штету насталу после 2007. године уколико је настала радњом извршеном после 2007. године. Директива се не односи ни на штету насталу тридесет година после штетне радње, емисије или инцидента. Директива се односи на оператере ,регулисаних делатности“. Већина индустријских делатности подпада под ову категорију.

\section{3. Врсте одговорности}

Директива усваја принцип строге одговорности за оператере делатности које су опасне по животну средину. У Анексу Директиве су таксативно набројане делатности за које постоји претпоставка штетности по животну средину. За све остале активности које нису набројане предвиђена је одговорност по принципу кривице. Строга одговорност покрива све врсте еколошке штете, одговорност по принципу кривице односи се само на штету над еколошким системом. Одређене врсте еколошке штете предвиђене међународним конвенцијама о грађанској одговорности (нуклеарне катастрофе, изливање нафте и сл.) изузете су из Директиве. С обзиром на широко постављене изузетке од одговорности и могуће одбране оператера, строга одговорност се може применити само у малом броју случајева када је одговорност за штету очигледна и ноторна, с обзиром на узрочну везу измеЂу штетног дела и настале штете. Оператер није одговоран за штету проузроковану од стране трећег лица која је настала упркос чињеници да је одговарајућа процедура заштите била примењена. Такође, оператер није одговоран ни за штету насталу услед више силе. Ослобађање од одговорности постоји и у случају штете проузроковане радњом за коју постоји дозвола или одобрење надлежног органа, али ово може да доведе до различитог третмана оператера у случају прекограничне штете када се поставља питање да ли дозвола издата у земљи штетне радње ослобађа одговорности за штетне последице те радње настале у другој земљи чланици.

Директива о Еколошкој одговорности има за циљ да обезбеди буђење еколошке свести код предузетника и њихово фокусирање на утицај активности које спроводе, као и да превентивно отклањају узроке могуће штете, насупрот чекању да до штете дође и накнадном разматрању регулатива које би могле у том случају бити примењене. Директива је базирана на принципу „загађивач плаћа“ чиме се настоји обезбедити да загађивач плаћа, односно одговара за нанету штету, а не да то чине порески обвезници. Осим тога, Директива има за циљ да установи неке опште оквире који би се тицали загађивања околине, како би спречила предузетнике да своје послове дислоцирају - селе у друге државе чланице зато што су тамо законске одредбе које се тичу животне средине флексибилније или не постоје. Државе чланице су имале времена до Маја 2007. године да имплементирају Директиву, међутим, многи нису испоштовали овај рок. 
Одговорност пада на оператере - руководиоце, односно свако лице које води или контролише активности које из своје основне делатности. Државе чланице могу да прошире одговорност и на лица која располажу са одређеном економском моћи у вези са реализацијом таквих активности. Активност која је у опису делатности је она активност која се извршава током економске активности предузећа или компаније, без обзира на то да ли је она приватна или јавна, профитабилног или непрофитабилног карактера.

Директива се односи на случајеве наношења штете животној средини које су изазване или су резултат активности из делатности оних који такве активности контролишу, ако је штета нанета: а) биима и природним стаништима која су заштићена Директивом о природним стаништима из 1992. године и Директивом о дивљим птицама из 1979. године; б) водама које су заштићене оквирном Директивом о заштити вода из 2000. године и в) гађење земљишта које ствара значајан ризик у смислу повреде људског здравља.

За одређене активности високог степена ризика, предвиђена је одговорност за све три категорије штете нанете животној средини и примењује се строга одговорност. Ове активности високог степена ризика укључују постројења која подлежу Интегрисаној превенцији загађења и Директиви о контроли, а контрола отпада подлеже оквирној Одлуци о отпаду или Директивама о спаљивању отпада. Чиниоци других активности могу се такође сматрати одговорним за штету нанету заштићеним врстама и заштићеним приридним стаништима уколико се утврди њихова кривица или занемаривање.

Уколико постоји непосредна претња наношења штете животној средини, оператер мора без одлагања да предузме мере како би штета била сведена на минимум. Ако ове мере неће спречити оштећење, оператери морају да информишу надлежне власти у најкраћем могућем времену. Мере које ће се предузети зависиће од врсте штете за који постоји претња да ће се десити. Државне власти могу наложити оператеру које мере треба да предузме или да сами предузму мере ако оператер у томе не успе, ако је руководеће лице тренутно недоступно или ако се од њега не захтева да преузме терет трошкова.

Онда када је до наношења штете по животну средину дошло, оператер мора да обавести надлежне власти о ситуацији и да истовремено предузме мере којима ће контролисати и управљати загађивачима како би спречио даље ширење штете и неповољне ефекте на људско здравље. Државне власти могу захтевати да оператер предузме мере санације или ће они сами предузети мере под околностима горе наведеним. 
Оператер нису одговорни за трошкове превентивних или мера санације уколико је штету проузроковало треће лице, ако су предузете прописане мере безбедности, или ако је штета проузрокована у сагласности са налогом или наредбом органа државне власти. Директива такође државама даје дискреционо право да одлуче да ли ће ослободити оператера одговорности ако штета резултира из неодобрене активности или ако може показати да се наношење штете није очекивало, односно да није постојао разлог да се одређена активност може показати штетном, у складу са научним и техничким сазнањима у моменту када је до наношења штете дошло.

Под околностима стварне или могуће штете по животну средину, трећа лица су овлашћена да траже од власти да предузму мере. Узевши да захтев за предузимање мера на прихватљив начин показује да штета по животну средину постоји, надлежне власти то морају узети у обзир.

\section{4. Осигурање од штете}

Према Директиви, предузеће у Европи се може осигурати од одговорности за отклањање еколошке штете, међутим, тренуто је могуће осигурати само штету од „више силе“ (тзв. акцидентно загађење) ${ }^{8}$, а собзиром да је она самом Директивом изузета од одговорности, овај вид осигурања је беспредметан. Пракса осигуравајућих друштава ће дати одговор да ли ће и на који начин проступити осигурању еколошке штете стварањем нових врста полиса које су алтернативне класичном осигурању од одговорности које само делимично дотиче еколошку штету. Треба напоменути да финансијско покриће од одговорности није обавезно већ је остављено самим државама да о томе одлуче. Ипак, недостатак понуде осигурања може да доведе и до развоја других форми финансијског покрића што ће несумњиво повећати трошкове заштите од одговорности, чиме ће се постићи супротан ефекат у односу на превентивну сврху Директиве. Као прелазно решење за превазилажење проблема до успостављања стабилног тржишта осигурања може бити покриће од одговорности и финанасирање накнаде штете путем еколошких фондова који већ постоје у појединим државама чланицама и неким земљама источне Европе. ${ }^{9}$ Сврха ових фондова је да обезбеди средства из једног или више извора ради дефинисања и управљања одговорности за еколошку штету. Еколошки фонд може прикупљати средства и ради заштите, унапређења и развоја животне средине.

\footnotetext{
${ }^{8}$ Bergkamp L., Corporate Governance and Social Responsibility: A New Sustainability Paradigm?, European Environmental Law Review, May 2002, стр.298.

${ }^{9}$ Више видети:: Hawk N., Financing Environmnetal Improvement: the Use of Environmental Funds in EU and CEE Countries, European Environmental Law Review, April 2003, стр. 113-120.
} 
Директива подстиче све државе чланице да развију системе за обавезну финансијску сигурност. Следеће државе су се обавезале да ће развити такве системе у вези са Директивом:

- Португалија (1.1.2010)

- Шпанија (30.04.2010)

- Грчка (2011)

- Мађарска (2010)

- Румунија (2010)

- Бугарска (01.01.2011)

- Словачка (2012)

- Чешка (01.01.2013)

Бројне земље су такође поставиле правне обавезе за операције које спадају под режим строге одговорности да би показале финансијску сигурност која би могла да надокнади штету ако оператер није у могућности да плати. Португал и Бугарска су увеле такве режиме, а Шпанија, Грчка, Мађарска, Чешка, Румунија и Словенија, тек треба да спроведу своје обавезе. Тамо где је осигурање доступно, то је углавном изабрана могућност.

Финансијска сигурност може имати бројне форме, укључујући обвезнице, депоноване рачуне, кредите, и одговарајуће осигурање. Последње је обично најефикасније и може бити преферирано од стране власти. Потребно је напоменути да Директива није једини регулаторни програм у Европи који може захтевати финансијске гаранције, ту спадају и Интегрисана превенцију загађења и дозволе контроле, управљање отпадом и лиценце за рударство и каменоломе. У додатку свим обавезним потребама финансијске сигурности, постоје значајне празнине у стандардним програмима када се ради о оштећењу животне средине. Главни недостаци полиса су: 1.покриће за штету нанету животној средини и посебно процес рестаурације; 2. покриће за штету нанету животној средини постепеним загађивањем; и 3.покриће за штету изазвану догађајима који нису загађење, као што је пожар.

Иако су се обавезале на неки вид финансијске сигурности, државе чланице нису усвојиле нити објавиле никаква правила, као ни смернице за имплементацију. Шпанија је на пример усвајила приступ заснован на шаблонској процени излагања ризика. Вероватно ће финансијска сигурност корак по корак бити уврштена у званичне распореде, током одређеног временског периода у сагласности са задатим роковима. Без обзира на будуће потребе за финансијском сигурношћу, компаније имају неограничену одговорност под условима Директиве и имплементације националних закона.

Када постоји осигурање, важно је да осигуравајуће друштво има одсек за екологију, да је организовано и способно да промптно одгово- 
ри на еколошке тужбе и да може да прикаже дугорочне обавезе за заштиту средине.

Док је финансијски концепт еколошке одговорности предвиђен Директивом још увек млад у Европској унији и без сумње је успорен тренутном економском ситуацијом, представља несумљиво значајну промену и добру прилику за осигуравајућу индустрију. Осигурање је, по виђењу многих, најочигледнији и вероватно најефикаснији вид решења за задовољавање потреба финансијске концепције предвиђене Директивом. Пребацивање финансијских последица ризика по животну средину на тржиште осигурања треба да буде главна тачка разматрања за компаније, било да законодавство тај корак охрабрује или не. Док многе организације неће предузети ништа, осим ако се приморају законским или уговорним захтевима, евидентно је да пошто се свест о претњама по животну средину развила, развиће се и потреба за осигуравајућим решењима. Компаније које уважавају важност таквих ризика и имају потребу да их стратешки контролишу, такође истичу да ће осигурање бити ефикасно средство које ће подржати ову стратегију. Тржиште осигурања је добро установљено у Великој Британији и другим државама чланицама, али одскора се фокусирало на „оперативне“ ризике за животну средину (они ризици који долазе као резултати њихових пословних активности). Постоји простор за развој, али стручњаци у осигурању овог сектора побринули су се да ова врста осигурања буде приступачна за све организације (компаније), без обзира на њихову величину или сектор. Свакако, ова врста осигурања није само за велике интернационалне корпорације јер велики број лица, од малих породичних фирми до глобалних организација, усваја овај ниво контроле ризика. Тренутни економски услови чине ситуацију тежом за многе, у процени ризика или куповини одговарајућег осигурања, али компаније морају да се запитају да ли су у стању да приуште себи последице неосигураних догађаја.

Без сумње, Директива о еколошкој одговорности представља значајан корак у развоју права животне средине. У појединим државама чланицама у којима прописи о животној средини нису развијени, Директива је донела велике и значајне промене. Без обзира на активности спровођења, промене у законодавству су позитиван подстрек у порасту свести компанија о њиховим еколшким одговорностима, које су праћене корпоративном одговорности широм сектора. Репутациони ризик је такође битан фактор, с обзиром да ће купци, акционари, инвеститори и други сигурно више обраћати пажњу на то колико компанија придаје важности заштити животне средине. Док компаније постају свесније ризика по животну средину, препознавање последица остаје дискутабилно - упркос законодавним подстрецима. Стављање акцента на озбиљност и тежину загађења, значи да ће 
предузећа, без обзира на величину и делатност, превидети сопствени утицај на животну средину, при чему финансијске последице за сваку компанију су различите. Па тако, трошкови санације штете нанете животној средини могу лако бити апсорбоване од стране једне организације, али могу угрозити солвентност друге.

\section{5. Имплементација Директиве о еколошкој одговорности - пример Немачке ${ }^{10}$}

Еколошка одговорност у Немачкој заснована је на три главна принципа:

- принцип превенције циља на избегавање или минимализацију могућности загађења на првом месту (власти могу да се умешају и интервенишу чак и ако се загађење још није десило);

- принцип ,загађивач плаћа“ значи да ће свако ко је одговоран за изазивање штете по животну средину бити одговоран за трошкове санације;

- принцип сарадње значи да еколошки услови морају бити развијени у уској повезаности са јавним и приватним организацијама.

Немачки прописи о животној средини су углавном донети на савезном нивоу. Извршна власт је препуштена чланицама. На савезном нивоу важну улогу имају Министарство за заштиту животне средине и Агенција за заштиту животне средине. Немачка је једна од држава у којој се најтеже проналази одговарајуће осигурање због слојевитих и разноликих регулатива. Иако је осигурање доступно, осигуравачи су веома строги по питању својих услова.

Немачка се сматра „еколошком државом“, будући да сматра заштиту животне средине једним од својих најважнијих задатака. Као и у многим другим земљама, тешки инжењеринг и индустријске компаније (као што су рафинерије, хемијска постројења и фабрике папира), за које се највише очекује да ће изазвати загађење животне средине, подлежу специјалним захтевима кад се ради о добијању дозволе. Уколико је компанија директно одговорна за загађење које представља опасност за опште здравље и околину, власти могу да предузму потребне мере које укључују потражњу измирења трошкова за санацију. Немачки Савезни Врховни Суд је посебно олакшао правила о доказима и обрнуо терет доказивања. Судови су такође

10 За искуства појединих држава чланица ЕУ у погледу имплементације Директиве о еколошкој одговорности видети: Implementation of the Environmental Liability Directive, House of Commons Environment, Food and Rural Affairs Committee, Sixth Report of Session 2006-07, Published on 12 July 2007 by authority of the House of Commons, London: The Stationery Office Limited и The implementation of the European Union Environmental Liability Directive Briefing on the main issues arising in relation water, http://www.rspb.org.uk/Images/eldwater_tcm9-153637.pdf 
применили концепт ,дужности да се заштити јавност“ на еколошку одговорност. Свако ко ствара могућу опасност по животну средину има дужност да предузме разумне мере опреза и превенције против наношења штете трећим лицима. Одређене радње деградације животне средине сматрају се кривичним делима, укључујући загађење воде или ваздуха изазвано шкодљивим супстанцама, одбацивање отпада које прети угрожавањем животне средине, и неодобрено руковање инсталацијама које су опасне по средину. Године 2007., Немачка је усвојила закон којима је Директива о еколошкој одговорности имплементирана у национално законодавство. Законом су прецизиране одредбе Директиве, а уведени су и нови облици одговорности. Осим тога постоје две важне додатне одредбе према којима је предвиђена могућност да држава донесе одлуку да ли ће дозволити да оператер одговара за еколошку штету у случају да је за обављање своје делатности добио дозволу од државе. Невладине организације имају право да захтевају да се предузму мере санације, чак и услучајевима да немају конкретан правни интерес.

\section{6. Имплементација Директиве о еколошкој одговорности - пример Француске}

У Француској компаније нису обавезне да се осигурају у вези са животном средином, иако је изливање нафте било „болна“ илустрација тога како док се повећава степен одговорности, мора да се повећа и финансијско покриће. Право животне средине у Француској је добро уређено, а Директива о еколошкој одговорности је имплементирана у Августу 2008. године. За разлику од других држава чланица, у Француској не постоји правна обавеза да се купи финансијска сигурност за случаје ризика наношења штете животној средини. Остаје на оператеру да одлучи о томе

У Августу 2009. године, Француска влада је објавила еколошку катастрофу у једном од најлепших европских природних резервата, након што се нафта излила из једне од подземних цеви у јужном региону Вouches-du-Rhone. Више од 4000 кубних метара сирове нафте разлило се на преко 5 хектара земљишта. Кроз цевовод је преношено 23 милиона тона сирове нафте годишње рафинеријама и петрохемијским постројењима у Француској, Немачкој и Швајцарској. Трошкови чишћења су износили око 20 милиона евра према неким извештајима. У овом случају, суд је донео одлуку да оператер није био везан строгим правилима о одговорности. Као резултат инцидента, међутим, дошло је до промене у закону у смислу да тешке индустријске активности у будућности морају да подлежу режиму строге одговорности. Што значи да терет доказивања пада на самог оператера. 
Инцидент пружа осигуравајућим друштвима и контролорима ризика увид у могуће трошкове везане за загађивање. Велике компаније су почеле да схватају значај осигурања у контексту животне средине што је допринело сталном порасту на тржишту осигурања. Међутим, свеукупно гледано, преузимање еколошких осигуравајућих производа у Француској од стране великих индустрија остаје на ниском нивоу. Компаније средње величине се посебно углавном уздржавају од куповине специјализоване еколошке полисе. Процене кажу да у Француској има око 10000 полиса, а чак око два милиона индустријских компанија.

\section{7. Европска Директива о еколошкој одговорности и њена примена у Великој Британији}

У Великој Британији, Енглеска је имплементирала Директиву у Марту 2009. године заједно са Велсом, Шкотском и Северном Ирском које су се затим придружиле. У том смислу су донете посебне уредбе које важе за штете нанете на дан или након 1. Марта 2009. године. У Уредбама су садржане одредбе из саме Директиве, а једино проширење везано је за убрајање биодиверзибилне штете по врсте или природна станишта на подручју посебног научног интереса. Различити органи извршне власти су обухваћени овим уредбама као што је Агенција за животну средину. Локалне власти имају овлашћење да врше превенцију и санацију земљишта ако су активности прописане од стране локалних власти. У супротном, Агенција је надлежна у случајевима загађења вода, природе, за биодиверзибилна загађења земљишта, локалне власти за загађења земљишта, а Државни секретаријат за обална биодиверзибилна загађења. Уколико постоји више врста загађења, постоји заједничка надлежност за решавање у таквим случајевима. Одговорност предвиђена уредбама је заједничка и појединачна - оператер може да позове на договорност било ког другог одговорног оператера. Одређене врсте загађења су искључене из уредби, као нпр. нафтно загађење које потпада под примену међународних конвенција, као и радиоактивност која је регулисана Актом о нуклеарним инсталацијама (1965). Термин „штета“" није дефинисан у уредбама него у самој Директиви, као мерљива негативна промена у природном ресурсу (пример, заштићене врсте и природна станишта, вода и земљиште) или мерљива оштећења природних ресурса (пример, функције изведене од стране природног ресурса за добробит другог ресурса или јавности) која могу бит директне или индиректне.

Према уредбама прописане казнене одредбе се односе на непредузимање свих расположивих мера и радњи у превенцији наношења штете по животну средину или спречиту ширења штетених последица, неинформи- 
сању да је дошло до загађивања околине (или друге штете за коју постоје основи да ће постати загађење околине) и/или непосредне претње такве штете или неусклађивање са захтевима о потребним мерама санације.

Уредбе постављају нови сет обавеза и одговорности на широк спектар пословања и то.

- обавезе само-пријављивања према уредбама значе да се системи интерног пријављивања и процене ризика морају осмислити посебно;

- у неким случајевима, мораће се размотрити напредна процена могућих ризика загађења околине или неке друге штете, као и потребне мере које се требају предузети;

- неки оператери могу одлучити да предузму процене почетног стања својих поседа;

- откривање загађења или штете по животну средину (или друге штете за коју постоје реални основи да се верује да ће постати загађење животне средине) током продаје или куповине могу бити повод за захтеве о објављивању тј. информисању надлежних власти о томе, или ће захтевати од странака да траже утврђивање дговорности за преузети ризик.

У Великој Британији постоји веома развијено и софистицирано тржиште за осигурање животне средине. Предузећа су изложена могућности тешких казни према Директиви и сматрају се одговорним за штету коју нанесу вршењем активности на својим поседима, чак иако се штета догодила због активности претходних власника. Прописи Велике Британије предвиђају одговорност власника поседа за стање животне средине и штету нанету животној средини на том поседу, независно од тога да ли је она нсатала и пре његовог власништва, па је веома важно да власници поседа буду упознати са историјатом њихових земљишта и поседа. На крају треба поменути да су многе компаније прошириле своје полисе опште одговорности на изненадне и случајне догађаје, али не постоји сигурност да ли ће те полисе одговарати новим мерама санације.

\section{8. Неке специфичности примене европске Директиве о еколошкој одговорности у Шпанији}

У Шпанији, кршење бране на Болиден руднику близу Севиље у Априлу 1998. године представља једну од највећих еколошких инцидената у историји те земље. Пукотина је ослободила око пет милиона кубних метара токсичног раствора, који је садржао смртоносне нивое олова и тешких метала чиме је уништена локалну средина и загађено 40км две локалне реке као и њива и фарми. Укупно, преко 40 тона рибе је угинуло, и око 5000 гусака, као и 20000 водених птица. Мере санације захтевале су ископавање 12 милиона тона загађеног земљишта и резултирале су тоталним економских крахом у том регио- 
ну (400 милиона евра). На основу оваквог искуства, Шпанија је усвојила најстрожији приступ употребе Директиве и еколошкој одговорности. Директива о еколошкој одговорности је имплементирана у Шпанији Априла 2007. године, али фактички се са њеном применом отпочело тек 2010. године.

Ипак, испитивање 700 шпанских компанија, које је спровело TNS Global Market Research показало је да је присутан значајан ниски ниво еколошке свести и о ризицима који ће утицати на пословање. ${ }^{11}$ Ово истраживање, објављено у Августу 2011. године, такође је показало недостатак знања о доступним полисама осигурања како би се компаније обезбедиле од могућих ризика. Ово је показало да више од половине предузећа немају одговарајуће покриће. Али што је још алармантније, преко $30 \%$ њих се изјаснило да неће предузети ништа да се заштите од могућих еколошких незгода.

\section{9. Закључна разматрања}

Право животне средине и одрживи развој представљају два дела једне целине и апсолутни приоритет данашњице. Одрживи развој је могућ уколико се посматра са три аспекта социјалног, економског аспекта животне средине. Одрживи развој се не може постићи уколико се природни ресурси и енергија троше бржим темпом него што је планети потребно да их обнови, или уколико се отпад ствара брже него што може да се разложи. ${ }^{12}$ Због тога је потребно створити услове за одрживи развој, а један од корака учињених у том правцу је доношење Директиве о еколошкој одговорностина нивоу Европске уније. Ипак, сама за себе, Директива није довољна за остварење одрживог развоја и због тога је потребно даљи развој усмерити у правцу јачања еколошке и друштвене одговорности предузећа - концепта који се ослања на добровољно активно учешће и допринос предузећа у стварању напреднијег друштва и здравије животне средине. ${ }^{13}$ Корпоративна одговорност предузећа захтева активан рад на развијању најбоље праксе у организовању рада, перманентном стручном усавршавању, једнаком третману запослених, интеграцију у друштвени систем и остварење одрживог развоја. Актива улога самих загађивача у овом контексту постаје императив савременог друштва која уз подизање еколошке свести загађивача треба да омогући стварање широког поље деловања и активну улогу невладиног сектора у заштити животне средине и одрживог развоја.

11 http://www.insuranceinsight.eu/insurance-insight/news/2085955/spanish-companieslack-environmental-risk-awareness

${ }^{12}$ Shelton D., Course 3 - Techniques and Procedures in International Environmental Law in UNITAR Programme of Training for the Application of Environmental Law, 2nd edition, UNITAR, Geneva 2004, Предговор.

${ }^{13}$ Berkamp L., op.cit., стр. 138. 
Bojan Pajtić, Ph.D., Assistant Professor

Faculty of Law Novi Sad

\title{
Environmental Liability
}

\begin{abstract}
Given the growing importance of the issue of responsibility for the damage and the danger of damage in the context of environmental protection at EU level, in this paper is specially treated so-called problems environmental responsibility and its regulation at the EU level, as well as implementation of this institution in some national legislation. The analysis was performed looking at ways of starting to regulate environmental matters under the Directive on environmental liability, and special emphasis is placed on the implementation of this Directive in individual EU countries such as Great Britain, Germany, Spain and France. Given that environmental protection is one of the area divided jurisdiction where EU bodies share equal responsibility with the national administrations of EU member states, ultimate goal is not only to protect the environment, but to promote the concept of improving the quality of the environment. In this context, the role of companies in the EU and the world is that in addition to taking legally required environmental protection measures, conduct additional environmental programs under the auspices of the increasingly popular corporate social responsibility.
\end{abstract}

Key words: environmental responsibility, environmental damage, civil law, compensation for damage, polluter pay principle 